\title{
Innovative Instrument for the Field Continuous Monitoring of Dissolved Gases in Environmental Studies
}

\author{
Eliot Chatton $^{1 *}$, Thierry Labasque ${ }^{2}$, Aurélie Guillou ${ }^{1}$, Paul Floury $^{3}$, Luc Aquilina ${ }^{2}$, Virginie Vergnaud ${ }^{1}$ \\ ${ }^{1}$ Univ Rennes, OSUR, UMS 3343, Plateforme Condate Eau, F-35000 Rennes, France \\ ${ }^{2}$ Univ Rennes, CNRS, Géosciences Rennes, UMR 6118, Plateforme Condate Eau, F-35000 Rennes, France \\ ${ }^{3}$ Institut Physique du Globe de Paris (IPGP) - CNRS and Université Sorbonne Paris-Cité, 1 rue Jussieu, 75238 Paris, France
}

Corresponding Author Email: thierry.labasque@univ-rennes1.fr

https://doi.org/10.18280/i2m.200406

Received: 23 June 2020

Accepted: 4 February 2021

\section{Keywords:}

dissolved gases, noble gases, reactive gases, field measurements, continuous monitoring, critical zone

\begin{abstract}
Dissolved gases are particularly relevant tools for the investigation of environmental processes. Indeed, their solubility being a function of the variables of physical state of the medium (temperature, pressure, salinity), the dissolved noble gases are for instance good indicators of equilibrium conditions with the atmosphere and mixing of water bodies. Dissolved gases can also inform the biogeochemical functioning of natural systems by providing information on major processes such as photosynthesis, respiration or denitrification. Classical methods relying on the sampling, the storage and the ex situ analysis of water samples for the measurement of dissolved gases suffer from the difficulty of taking sufficiently frequent and representative samples as well as the analyte preservation. High-frequency in situ measurement of dissolved gases is therefore the most relevant for the study of environmental processes. The use of Membrane Inlet Mass Spectrometer (MIMS) technology provides access to high frequency measurements of a large set of dissolved gases in the field ( $\mathrm{He}, \mathrm{Ne}, \mathrm{Ar}, \mathrm{Kr}, \mathrm{Xe}, \mathrm{N}_{2}, \mathrm{O}_{2}, \mathrm{CO}_{2}, \mathrm{CH}_{4}, \mathrm{~N}_{2} \mathrm{O}, \mathrm{H}_{2}$ ) which offers a real opportunity for environmental studies.
\end{abstract}

\section{INTRODUCTION}

Dissolved gas measurements are valuable tools for the investigation of physical, geochemical and biological processes taking place in aquatic environments. In this respect, noble gases ( $\mathrm{He}, \mathrm{Ne}, \mathrm{Ar}, \mathrm{Kr}, \mathrm{Xe}$ and $\mathrm{Rn}$ ) are unaffected by biogeochemical processes and then enable to capture critical information on key physical processes in environmental studies such as atmosphere-hydrosphere exchanges with gas transfer coefficients $[1,2]$, groundwater recharge conditions with noble gas temperatures $[3,4]$, residence time distribution in aquatic environments with ${ }^{4} \mathrm{He},{ }^{39} \mathrm{Ar},{ }^{81} \mathrm{Kr}$ or ${ }^{85} \mathrm{Kr}[5,6]$, mixing of different water bodies with ${ }^{222} \mathrm{Rn}$ [7] or solute transport in porous media [8]. On the contrary, reactive dissolved gases $\left(\mathrm{O}_{2}, \mathrm{H}_{2}, \mathrm{~N}_{2}, \mathrm{NO}, \mathrm{N}_{2} \mathrm{O}, \mathrm{CO}_{2}, \mathrm{CO}, \mathrm{CH}_{4}, \mathrm{H}_{2} \mathrm{~S}\right)$ are intrinsic markers of the biogeochemical processes taking place in aquatic environments. These dissolved gases inform particularly on geochemical cycles of C, N, S and ecosystems functioning [9-13] through key biogeochemical processes such as photosynthesis, respiration, nitrogen removal reactions, rock weathering, etc.

Therefore, dissolved gas measurements encompass several assets as they provide critical information on a diversity of processes and also because most of them can be analysed using a single equipment (gas chromatograph or mass spectrometer). However, difficulties can arise when it comes to measuring low abundant (Xe for instance) or highly reactive $\left(\mathrm{O}_{2}, \mathrm{CO}_{2}\right.$ or $\mathrm{H}_{2}$ for instance) dissolved gases. As a matter of fact, dissolved gas sampling is not trivial as many fields, storage and lab parameters could potentially affect the sample representativeness and the analyte preservation.

Consequently, field dissolved gases measurements consist in a promising alternative to classical methods relying on sampling and ex situ analyses. In this respect, dissolved gas specific sensors $\left(\mathrm{O}_{2}, \mathrm{CO}_{2}\right.$ and $\left.\mathrm{CH}_{4}\right)$ have been widely developed for environmental studies as they provided both the opportunity to overcome the issues related to sampling and the possibility to perform long-term high-frequency monitoring.

Over the last decades, membrane inlet mass spectrometers (MIMS) received great interest from environmental scientists for their capacity of high-frequency measurement of various dissolved gases at the laboratory [14-22]. Recently, the improvements of MIMS technology allowed considerable progresses in the portability, miniaturisation, sensitivity, and analytical versatility of the instruments enabling the field highfrequency measurement of several dissolved gases [8, 23-35].

In this paper, we detail a new approach for the field continuous measurement of dissolved gases in aquatic environments with a CF-MIMS (Continuous Flow Membrane Inlet Mass Spectrometer). This technique allows the in situ high-frequency monitoring of dissolved noble and reactive gases ( $\mathrm{He}, \mathrm{Ne}, \mathrm{Ar}, \mathrm{Kr}, \mathrm{Xe}, \mathrm{N}_{2}, \mathrm{CO}_{2}, \mathrm{O}_{2}, \mathrm{CH}_{4}, \mathrm{~N}_{2} \mathrm{O}$ and $\mathrm{H}_{2}$ ) directly on water flows. After presenting the details of the analytical method and the calibration procedure, the field capabilities of the CF-MIMS are illustrated at the Orgeval Critical Zone Observatory through the in situ monitoring of the diurnal biogeochemical dynamics of the Avenelles River. 


\section{MATERIALS AND METHODS}

\subsection{System description}

Even though few MIMS systems are commercially available, the design and conception of the CF-MIMS was carried out by the private supplier Hiden Analytical (HPR-40). According to the specification requirements, the instrument dimensions $\left(52 \times 53 \times 54 \mathrm{~cm}^{3}\right)$, weight $(55 \mathrm{~kg})$ and shielding (reinforced frame mounted on Silent Bloc ${ }^{\circledR}$ ) make the CFMIMS a fairly mobile and resistant instrument designed for field experiments.

Although its robustness, the CF-MIMS consists in a cuttingedge instrument for dissolved gas measurements. Equipped with a membrane inlet connected to a quadrupole mass spectrometer, the CF-MIMS shown in Figure 1 allows the continuous permeation and detection of the gases dissolved in water flows.

\subsubsection{Membrane inlet}

The originality of the CF-MIMS lies in the introduction of the analytes (dissolved gases) directly into the vacuum of the mass spectrometer $\left(\mathrm{P}<5 \times 10^{-6}\right.$ Torr $)$ using a semi-permeable membrane which extracts a fraction of the dissolved gases (from $0.05 \%$ to $1.5 \%$ of the concentration) from flowing liquids (water flows in our case). The selection of a suitable membrane is therefore essential to ensure the optimal permeation and selection of the targeted dissolved gases. Laboratory experiments have been carried out at Hiden Analytical to select the best membrane for our purposes by comparing different types of membrane materials such as PDMS, $\mathrm{X} 44^{\circledR}$ polymer and biaxially oriented PET. With an enhanced selectivity to light gases $\left(\left(\mathrm{He} / \mathrm{N}_{2}\right)^{\mathrm{MIMS}} /\left(\mathrm{He} / \mathrm{N}_{2}\right)^{\text {water }}=170, \quad\left(\mathrm{Ar} / \mathrm{N}_{2}\right)^{\mathrm{MIMS}} /\left(\mathrm{Ar} / \mathrm{N}_{2}\right)^{\text {water }}=4\right.$ and $\left.\left(\mathrm{Xe} / \mathrm{N}_{2}\right)^{\mathrm{MIMS}} /\left(\mathrm{Xe} / \mathrm{N}_{2}\right)^{\text {water }}=0.4\right)$, the $\mathrm{X} 44^{\circledR}$ polymer (thickness $=0.05 \mathrm{~mm}$; diameter $=38 \mathrm{~mm}$ ) has been selected to design a suitable membrane for the CF-MIMS. Directly connected to the mass spectrometer vacuum, the membrane inlet (Figure 1) allows the continuous measurement of dissolved gases on water flows $(<10 \mathrm{~L} / \mathrm{min})$.

\subsubsection{Water entrapment}

In order to enhance the sensitivity of MIMS systems to low abundant gases, a cold trap can be installed just between the membrane inlet and the mass spectrometer [34]. This cold trap consists in a copper tube (1/8 inch diameter) placed in a cryogenic storage recipient filled with ethanol kept at $-100^{\circ} \mathrm{C}$ to trap the water vapour (most abundant gas in the mass spectrometer).

However, we do not use a cold trap anymore for practical reasons that might be worth explaining in this paper. For instance, the cold trap requires a long time to stabilise the signal of the continuously entering water vapour to a minimum value ( $>1 \mathrm{~h}$ depending on the trap size). Furthermore, the trapped water needs to be removed periodically to avoid the clogging of the copper tube which in turn, breaks the measurements continuity. Finally, continuously cooling the cold trap uses a lot of electrical power which is hardly available in the field.

\subsubsection{Ionisation}

After permeation, the analytes are ionised by electrons emitted by oxide coated iridium filaments. Optimisation of ionisation procedures can be performed to improve the signal/noise ratio by optimisation of the flow of ionising electrons (emission intensity from 20 to $5000 \mu \mathrm{A}$ ) or, to a lower extent, by experimental determination of optimal ionisation energies (electron energy from 4 to $150 \mathrm{eV}$ ). In the CF-MIMS, the standard ionisation procedure $(250 \mu \mathrm{A}, 70 \mathrm{eV})$ has been optimised by increasing the emission intensity in order to enhance the sensitivity to low abundant dissolved gases such as $\mathrm{Xe}(1000 \mu \mathrm{A})$.

\subsubsection{Mass spectrometer}

Once ionised, the analytes are guided inside the vacuum of a quadrupole mass spectrometer (Hiden Analytical HAL3F$\mathrm{RC}$ ) by an electromagnetic field which allows their separation according to their mass to charge ratios $(\mathrm{m} / \mathrm{z}$ ratios between 0.40 and $200.00 \mathrm{amu}$ ).

\subsubsection{Detection}

After separation, the ionised analytes are detected either by a Faraday cup (FC) or a single channel electron multiplier (SCEM). Finally, the CF-MIMS allows a direct and continuous measurement of dissolved gases at the high frequency of $0.5 \mathrm{~Hz}$ (one dissolved gas measurement every two seconds).

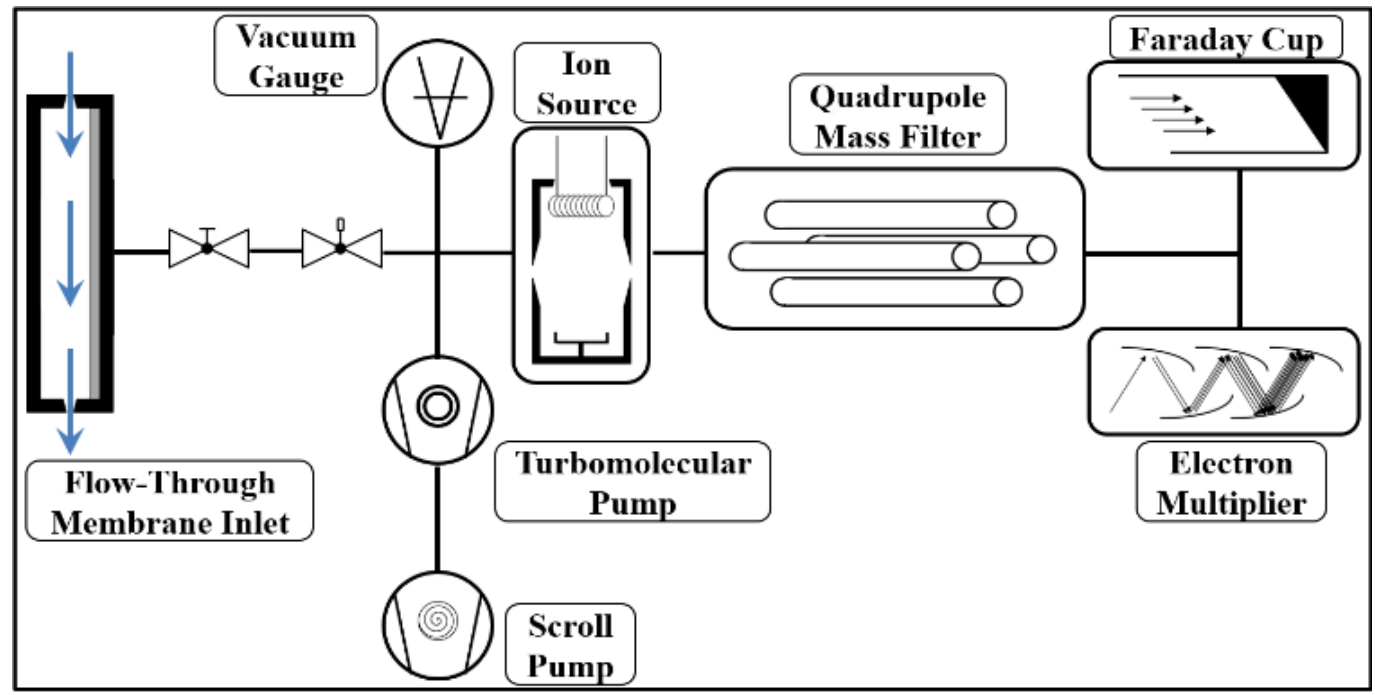

Figure 1. Technical description of the CF-MIMS based on the HPR-40 mass spectrometer (Hiden Analytical) 


\subsection{Signal processing and calibration}

\subsubsection{Normalisation}

The raw signals conveyed by the detectors are normalised by the sum of detected signals in order to convert these raw signals in partial pressures and account for the variations of dissolved gas inflows (changes in water dissolved gas composition) during the measurements.

\subsubsection{Calibration}

In order to translate the partial pressures measured by the CF-MIMS into gas concentrations it is necessary to define a proper calibration procedure. So as to account for the different membrane interactions with dissolved gas concentrations, the CF-MIMS is directly calibrated on water flows of known concentration. For the purpose, a calibration chamber has been built in order to saturate a water volume with different standard gas mixtures of known composition while preventing from any atmospheric exchange. The standard equilibrated water (SEW) is continuously brought from the calibration chamber to the membrane using a low voltage impeller pump allowing the monitoring of water saturation until stabilisation of the signals is achieved.

For each dissolved gas, the measured partial pressures can be converted into gas concentrations using either an internal and/or external calibration procedure. The internal calibration consists in the calculation of dissolved gas equilibrium concentrations of different SEWs using the laws of gas solubility in water [36-43]. The parameters required for the calculation of equilibrium concentrations such as air pressure, water temperature and salinity are continuously monitored in the calibration chamber. In addition, the calibration chamber includes an outlet valve allowing an external calibration by sampling each SEW for control analysis using classical gaschromatographic techniques (GC-TCD or GC-MS).

The calibration procedure is performed after connecting the membrane inlet to the mass spectrometer and should be implemented when the partial pressure baselines are stable (requiring about $1 \mathrm{~h}$ ). Calibration temporal stability has been investigated through a laboratory test that did not indicate any sign of instrumental drift over the 33 hours experiment. Therefore, when the calibration is achieved and as long as the membrane inlet remains connected, the CF-MIMS does not require further additional calibration. Nevertheless, regular sampling always ensures the validity of the calibration for long-term monitoring experiments.

The CF-MIMS calibration is performed at the same flow and temperature as the measurements. Water flow is controlled by an impeller pump serving the membrane. Calibrations and measurements are performed in the mobile laboratory conditioned at a controlled temperature. However, when natural waters show temperature variations while monitoring, the signals measured with the CF-MIMS must be corrected from temperature effects on the membrane gas transfer properties.

\subsubsection{Temperature sensitivity}

As a matter of fact, in some cases, membrane permeability and selectivity can vary during field monitoring experiments as a result of the evolution of experimental conditions such as the variation of water or membrane temperatures [8]. These changes alter the proportions of each dissolved gas inflow which in turn modifies the calibration equations (mathematical relations converting the partial pressures in dissolved gas concentrations).

A simple operational technique to remove these adverse effects on membrane transfer properties is to experimentally calibrate transfer functions for each analyte based on the measure of the evolution of the water partial pressure which is directly representative of the impact of experimental conditions on the measurements.

\subsubsection{Spectral overlaps}

The objective of the CF-MIMS is to measure the full suite of noble gases ( $\mathrm{He}, \mathrm{Ne}, \mathrm{Ar}, \mathrm{Kr}, \mathrm{Xe}$ ) as well as the some reactive dissolved gases $\left(\mathrm{N}_{2}, \mathrm{O}_{2}, \mathrm{CO}_{2}, \mathrm{H}_{2}, \mathrm{CH}_{4}, \mathrm{~N}_{2} \mathrm{O}\right)$. The simplest case consists in measuring these dissolved gases directly at their corresponding $\mathrm{m} / \mathrm{z}$. For instance, $\mathrm{He}, \mathrm{Ar}, \mathrm{Kr}$, $\mathrm{Xe}$ and $\mathrm{O}_{2}$ concentrations can be directly associated to the partial pressures calibrated respectively at $\mathrm{m} / \mathrm{z} 4,40,84,129$ and 32 .

However, noble and reactive dissolved gases coexist in natural waters and, unfortunately some of them arise at the same $\mathrm{m} / \mathrm{z}$ ratio creating spectral overlaps shown in Table 1 . Most of the time, the overlapping species are also among the targeted ones which inhibits the use of traps and getters [34] to remove the overlapping $\mathrm{N}_{2}, \mathrm{CO}_{2}, \mathrm{CH}_{4}, \mathrm{~N}_{2} \mathrm{O}$ and $\mathrm{Ar}$.

Table 1. Spectral overlaps detected at measured mass to charge $\operatorname{ratios}(\mathrm{m} / \mathrm{z})$

\begin{tabular}{|c|c|c|}
\hline $\mathbf{m} / \mathbf{z}$ & Targeted gas & Overlaps \\
\hline 12 & $\mathrm{CO}_{2}$ & $\mathrm{CH}_{4}$ \\
\hline 14 & $\mathrm{~N}_{2}$ & $\mathrm{~N}_{2} \mathrm{O}$ \\
\hline 15 & $\mathrm{CH}_{4}$ & $\mathrm{~N}_{2}$ \\
\hline 20 & $\mathrm{Ne}$ & $\mathrm{Ar}, \mathrm{H}_{2} \mathrm{O}$ \\
\hline 28 & $\mathrm{~N}_{2}$ & $\mathrm{CO}_{2}$ \\
\hline 30 & $\mathrm{~N}_{2} \mathrm{O}$ & $\mathrm{N}_{2}$ \\
\hline 44 & $\mathrm{CO}_{2}$ & $\mathrm{~N}_{2} \mathrm{O}$ \\
\hline
\end{tabular}

Without traps and getters, another way to remove overlapping species at a particular $\mathrm{m} / \mathrm{z}$ is to optimise ionisation settings. For instance, it is possible to enhance Ne ionisation to produce a signal of secondly ionised ${ }^{20} \mathrm{Ne}$ at $\mathrm{m} / \mathrm{z} 10$ $\left({ }^{10}\left(\mathrm{Ne}_{(\mathrm{II})}\right), 2000 \mu \mathrm{A}, 140 \mathrm{eV}\right)$ in order to avoid the spectral overlaps encountered at $\mathrm{m} / \mathrm{z} 20$ with ${ }^{20}\left(\operatorname{Ar}_{(\mathrm{II})}\right)$ and ${ }^{20}\left(\mathrm{H}_{2} \mathrm{O}\right)$.

For $\mathrm{N}_{2}, \mathrm{CO}_{2}$ and $\mathrm{N}_{2} \mathrm{O}$, the measurement method relies on the acquisition of multiple signals at $\mathrm{m} / \mathrm{z} 12,14,28,44$ when calibrating. For instance, high amounts of $\mathrm{CO}_{2}$ can produce small excesses on the $\mathrm{N}_{2}$ signal measured at $\mathrm{m} / \mathrm{z} 28$ which can be corrected using the linear relation with the $\mathrm{N}_{2}$ signal at $\mathrm{m} / \mathrm{z}$ $14\left(\mathrm{CO}_{2}\right.$ overlap free $)$. The same rationale applies to the excesses on the $\mathrm{CO}_{2}$ signal at $\mathrm{m} / \mathrm{z} 44$ due to overlapping $\mathrm{N}_{2} \mathrm{O}$ that can be separated (and potentially quantified) using the $\mathrm{CO}_{2}$ signal at $\mathrm{m} / \mathrm{z} 12\left(\mathrm{~N}_{2} \mathrm{O}\right.$ overlap free $)$.

For the remaining species, we chose to overcome the issue of spectral overlaps by normalising $\mathrm{H}_{2}, \mathrm{CH}_{4}$ and $\mathrm{N}_{2} \mathrm{O}$ signals at $\mathrm{m} / \mathrm{z} \mathrm{2}, 15$ and 30 respectively with the signal of the overlapping species $\mathrm{H}_{2} \mathrm{O}$ and $\mathrm{N}_{2}$ that are also found at $\mathrm{m} / \mathrm{z} 18$, 14 and 28 (instead of normalising with the sum of detected signals). This method consists therefore in measuring the ratios $(\mathrm{Pm} / \mathrm{z} 2$ / Pm/z 18), (Pm/z 15 / Pm/z 14) and (Pm/z 30 / $\mathrm{Pm} / \mathrm{z} 28$ ) which are constant in absence of $\mathrm{H}_{2}, \mathrm{CH}_{4}$ and $\mathrm{N}_{2} \mathrm{O}$ only controlled by $\mathrm{H}_{2} \mathrm{O}$ and $\mathrm{N}_{2}$. On the contrary, the deviations of $(\mathrm{Pm} / \mathrm{z} 2$ / Pm/z 18), (Pm/z 15 / Pm/z 14) and (Pm/z 30 / $\mathrm{Pm} / \mathrm{z} 28$ ) are proportional to $\mathrm{H}_{2}, \mathrm{CH}_{4}$ and $\mathrm{N}_{2} \mathrm{O}$ concentrations and can be calibrated using an offset (constant controlled by $\mathrm{H}_{2} \mathrm{O}$ and $\mathrm{N}_{2}$ ). 


\subsection{Measurement settings and analytical performances}

For each dissolved gas, laboratory experiments have been carried out to optimise ionisation procedures and evaluate the precision of the CF-MIMS measurements (expressed as the relative standard deviation, RSD), the quantification limits (QL), the sensitivity (S), the 90 percentile response time $\left(t_{90}\right)$ and the instrument consumption for reactive $\left(\mathrm{N}_{2}, \mathrm{O}_{2}, \mathrm{CO}_{2}, \mathrm{H}_{2}\right.$, $\mathrm{CH}_{4}, \mathrm{~N}_{2} \mathrm{O}$ ) and noble ( $\left.\mathrm{He}, \mathrm{Ne}, \mathrm{Ar}, \mathrm{Kr}, \mathrm{Xe}\right)$ dissolved gases. Table 2 shows the details of the analytical performances of the CF-MIMS

For each dissolved gas, the RSDs have been assessed for several concentration ranges which allowed observing the evolution of the analyte RSD as a function of its concentration following a power law relation. As a result, the RSDs shown in Table 2 correspond to the analytical precisions estimated for air equilibrated water concentrations at $\mathrm{T}=20^{\circ} \mathrm{C}$.

The QLs shown in Table 2 relate to the analyte concentration corresponding to a $\mathrm{RSD}=10 \%$ using the power law relation mentioned earlier. When such a RSD could not be achieved with the power law (for $\mathrm{He}$ and $\mathrm{O}_{2}$ ), the QLs shown are the detection limits (DLs) which are the concentrations related to the smallest signal that can be sensed by the detectors

As $\mathrm{CH}_{4}$ and $\mathrm{N}_{2} \mathrm{O}$ are measured at overlapped $\mathrm{m} / \mathrm{z}$, their QLs depend also on the analytical uncertainty of the overlapping gas at these $\mathrm{m} / \mathrm{z}$ ratios (respectively ${ }^{15}\left(\mathrm{~N}_{2}\right)$ and ${ }^{30}\left(\mathrm{~N}_{2}\right)$ ). As a result, Table 2 displays the estimated QLs for $\mathrm{CH}_{4}$ and $\mathrm{N}_{2} \mathrm{O}$ when $\mathrm{N}_{2}$ contents are in equilibrium with the atmosphere.

The $t_{90}$ shown in Table 2 relate to the measured response time for dissolved noble gases and for dissolved reactive gases The latter was extrapolated with respect to the response times of the dissolved noble gases as a function of their molar mass.

The dissolved gas measurements performed with CF-MIMS are obviously more precise for highly abundant gases $\left(\mathrm{N}_{2}, \mathrm{O}_{2}\right.$, $\mathrm{CO}_{2}$, Ar) than for the low abundant ones (Xe) and ranges between 0.2 and $6.0 \%$ which is fairly suitable for environmental studies. The CF-MIMS analyses are more sensitive and faster for light dissolved gases $\left(\mathrm{H}_{2}\right.$ and $\left.\mathrm{He}\right)$ than for the heavy and/or overlapped ones $\left(\mathrm{CO}_{2}, \mathrm{Xe}\right.$ and $\left.\mathrm{N}_{2} \mathrm{O}\right)$. The quantification limits are lower than $2 \mathrm{ppb}$ for the Faraday detector and lower than $40 \mathrm{ppt}$ for the SCEM detector which also fairly suitable for environmental studies.

Table 2. Measurement settings and analytical performances of the CF-MIMS

\begin{tabular}{|c|c|c|c|c|c|c|c|c|}
\hline Gas & $\mathbf{m} / \mathbf{z}(\mathbf{a m u})$ & Ionisation $(\mathrm{eV} / \mu \mathrm{A})$ & Detector & RSD (\%) & QL $(\operatorname{ccSTP} / g)$ & S (g/ccSTP) & $t_{90}(\mathrm{~s})$ & Cons $(\% / s)$ \\
\hline $\mathrm{He}$ & 4 & $70 / 250$ & SCEM & 2.0 & $5.0 \times 10^{-12}$ & 8260 & 8 & 1.4 \\
\hline $\mathrm{Ne}$ & 10 & $140 / 2000$ & SCEM & 5.0 & $5.0 \times 10^{-8}$ & 45 & 21 & 1.1 \\
\hline $\mathrm{Ar}$ & 40 & $70 / 250$ & Faraday & 0.2 & $6.5 \times 10^{-7}$ & 105 & 32 & 0.5 \\
\hline $\mathrm{Kr}$ & 84 & $70 / 1000$ & SCEM & 2.0 & $1.0 \times 10^{-9}$ & 40 & 86 & 0.1 \\
\hline $\mathrm{Xe}$ & 129 & $70 / 1000$ & SCEM & 6.0 & $3.0 \times 10^{-9}$ & 15 & 140 & 0.05 \\
\hline $\mathrm{N}_{2}$ & 28 & $70 / 250$ & Faraday & 0.2 & $5.5 \times 10^{-7}$ & 125 & 26 & 0.1 \\
\hline $\mathrm{O}_{2}$ & 32 & $70 / 250$ & Faraday & 0.2 & $6.0 \times 10^{-8}$ & 80 & 28 & 0.6 \\
\hline $\mathrm{CO}_{2}$ & 44 & $70 / 250$ & Faraday & 0.2 & $7.5 \times 10^{-7}$ & 3 & 34 & 0.2 \\
\hline $\mathrm{H}_{2}$ & 2 & $70 / 250$ & Faraday & 0.2 & - & 4625 & 5 & 0.2 \\
\hline $\mathrm{CH}_{4}$ & 15 & $70 / 250$ & SCEM & 2.0 & $2.5 \times 10^{-7}$ & 65 & 18 & 1.5 \\
\hline $\mathrm{N}_{2} \mathrm{O}$ & 30 & $70 / 250$ & Faraday & 0.5 & $1.0 \times 10^{-6}$ & 15 & 34 & 0.4 \\
\hline
\end{tabular}

\section{FIELD APPLICATION}

Our perception of hydrological and biogeochemical processes at the catchment scale is constrained by our ability to capture the information carried by rivers, both in terms of temporal distribution and quality of the data. In view of the temporal variety and variability of river biogeochemical dynamics, new exploration methods are currently developed on the basis of in situ high-frequency measurements [8, 44].

In line with this rationale, the CF-MIMS was arranged in a mobile laboratory (CRITEX Lab) and deployed in the Orgeval Critical Zone Observatory, France (https://gisoracle.irstea.fr/) to monitor the diurnal biogeochemical dynamics of the Avenelles River.

The Orgeval catchment is part of the French Critical Zone Research Infrastructure OZCAR ("Observatoires de la Zone Critique, Applications et Recherche") and consist in one of the most instrumented and documented river observatories in France, with 50 years of hydrological data (https://bdoh.irstea.fr/ORACLE/). The Avenelles River drains an area of $45 \mathrm{~km}^{2}$ in a sub-catchment in the Orgeval watershed sitting in the sedimentary carbonate-dominated Paris Basin. This perennial river is supplied by groundwater from the Brie aquifer dominated by $\mathrm{Ca}^{2+}, \mathrm{SO}_{4}{ }^{2-}, \mathrm{HCO}_{3}{ }^{-}$and $\mathrm{NO}_{3}{ }^{-}$ions.

For over two years, the Orgeval Critical Zone Observatory has benefited from the deployment of a River Lab which monitors every $40 \mathrm{~min}$ the long-term dynamics of major dissolved species $\left(\mathrm{Na}^{+}, \mathrm{K}^{+}, \mathrm{Ca}^{2+}, \mathrm{Mg}^{2+}, \mathrm{Cl}^{-}, \mathrm{SO}_{4}{ }^{2-}\right.$ and $\left.\mathrm{NO}_{3}{ }^{-}\right)$at the outlet of the Avenelles River [44]. In order to supplement the analytical capabilities deployed at this point, the CF-MIMS was installed next to the River Lab for two days during the low water period (August 2017, $\mathrm{Q} \approx 0.1 \mathrm{~m}^{3} / \mathrm{s}$ ) to monitor $\mathrm{He}$, $\mathrm{Ar}$, $\mathrm{N}_{2}, \mathrm{O}_{2}, \mathrm{CO}_{2}, \mathrm{CH}_{4}, \mathrm{~N}_{2} \mathrm{O}$ and $\mathrm{H}_{2}$ concentrations each 30 seconds over a $24 \mathrm{~h}$ cycle. In parallel to these continuous measurements, punctual analyses were carried out with a gas chromatograph (Micro-GC TCD Agilent 3000A) to compare the CF-MIMS data with a validated analytical method [45].

The results of this monitoring are shown in Figure 2 and Figure 3 for $\mathrm{O}_{2}, \mathrm{CO}_{2}$ and $\mathrm{Ar}$ data collected between 23/08/2017 10h23 and 24/08/2017 15h39. Figure 2 displays both the high frequency data from the CF-MIMS (red and blue circles) and the Micro-GC analyses performed on the collected samples (brown and orange squares). Figure 2 shows that $\mathrm{O}_{2}$ and $\mathrm{CO}_{2}$ concentrations have opposite trends as $\mathrm{O}_{2}$ maximum concentration $\left(\left[\mathrm{O}_{2(\mathrm{aq})}\right]=340 \mu \mathrm{mol} / \mathrm{L}\right.$ or else $114 \%$ sat $)$ is achieved when the $\mathrm{CO}_{2}$ reaches its lowest levels $\left(\left[\mathrm{CO}_{2(\mathrm{aq})}\right]=\right.$ $50 \mu \mathrm{mol} / \mathrm{L}$ or else $310 \%$ sat) around $14 \mathrm{~h} 00$. On the contrary, $\mathrm{CO}_{2}$ maximum concentration $\left(\left[\mathrm{CO}_{2(\mathrm{aq})}\right]=61 \mu \mathrm{mol} / \mathrm{L}\right.$ or else $360 \%$ sat) is achieved around $6 \mathrm{~h} 00$ when $\mathrm{O}_{2}$ levels are low $\left(\left[\mathrm{O}_{2(\mathrm{aq})}\right]=290 \mu \mathrm{mol} / \mathrm{L}\right.$ or else $104 \%$ sat $)$. Field high-frequency data recorded with the CF-MIMS show little dispersion $\left(\sigma_{\mathrm{O} 2}=\right.$ $0.59 \% \& \sigma_{\mathrm{CO} 2}=0.18 \%$ ) and neatly capture the slopes and 
trends in the diurnal fluctuations of $\mathrm{O}_{2}$ and $\mathrm{CO}_{2}$ concentrations. On the contrary, punctual measurements performed with the Micro-GC display a larger dispersion $\left(\sigma_{\mathrm{O} 2}=2.11 \% \& \sigma_{\mathrm{CO} 2}=\right.$ $1.85 \%$ ) and if punctual data produce roughly the same trends observed with the CF-MIMS, such data dispersion and low frequency sampling fails to reproduce the same observation quality (particularly if the sample were to be collected blindly).

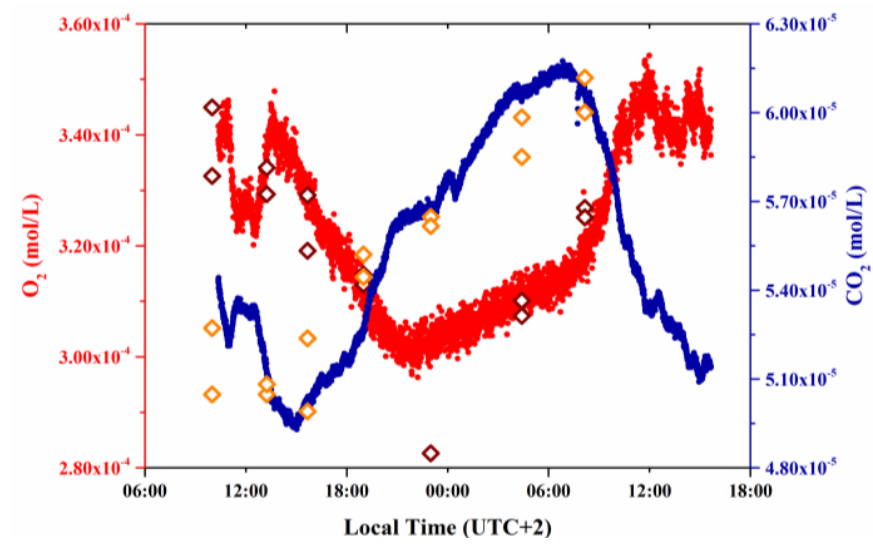

Figure 2. Evolution of dissolved $\mathrm{O}_{2}$ and $\mathrm{CO}_{2}$ concentrations in the Avenelles River. Red and blue circles show respectively $\mathrm{O}_{2}$ and $\mathrm{CO}_{2}$ data recorded with the CF-MIMS while brown and orange squares show respectively $\mathrm{O}_{2}$ and

$\mathrm{CO}_{2}$ data analysed with a Micro-GC after head-space extraction of the collected samples [45]

Figure 2 shows that $\mathrm{O}_{2}$ and $\mathrm{CO}_{2}$ data recorded with the $\mathrm{CF}$ MIMS are in good agreement with $\mathrm{O}_{2}$ and $\mathrm{CO}_{2}$ concentrations measured with the validated analytical method $\left(\mathrm{RSD}_{\mathrm{O} 2}<2 \%\right.$ and $\mathrm{RSD}_{\mathrm{CO} 2}<2 \%$ ). Furthermore, the comparison between high-frequency data (CF-MIMS) and punctual data (MicroGC) illustrates the benefits of continuous and in situ measurements over classical methods involving sampling and laboratory analyses both in terms of temporal distribution and quality of the dissolved gas data. The latter becomes critical when it comes to the observation and the discrimination of a potential combination of natural phenomena with different kinetics.

Figure 3 displays the ratios $\mathrm{O}_{2} / \mathrm{Ar}$ and $\mathrm{CO}_{2} / \mathrm{Ar}$ which allow capturing the dynamics of biogeochemical processes controlling dissolved $\mathrm{O}_{2}$ and $\mathrm{CO}_{2}$ concentrations in the river while subtracting the diurnal thermodynamic effects on dissolved gas equilibria recorded by dissolved Ar data.

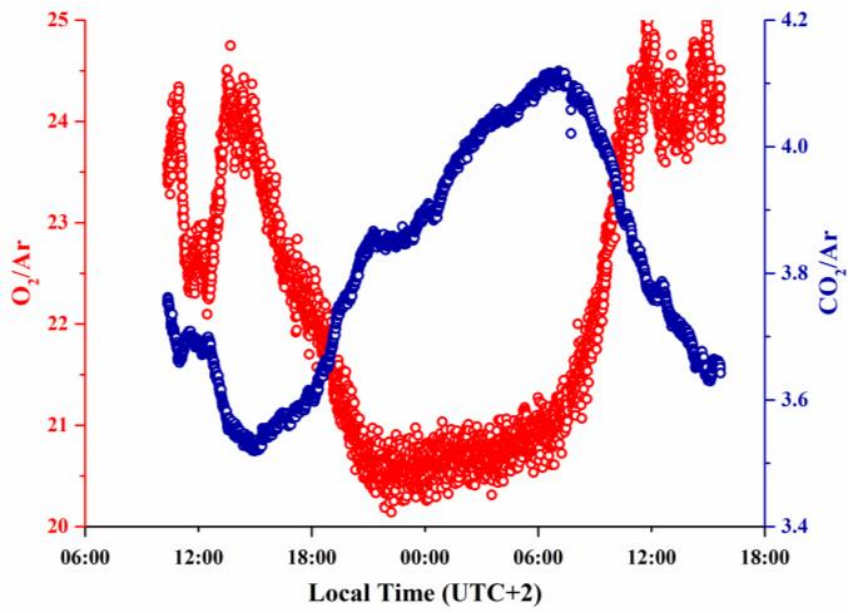

Figure 3. Evolution of the $\mathrm{O}_{2} / \mathrm{Ar}$ (red circles) and $\mathrm{CO}_{2} / \mathrm{Ar}$ (blue circles) ratios in the Avenelles River
Similarly to Figure 2, $\mathrm{O}_{2}$ and $\mathrm{CO}_{2}$ diurnal trends are divergent in Figure 3. During night-time (20h30 - 7h00), $\mathrm{CO}_{2} /$ Ar ratios increase constantly (since 14h30) from 3.5 to 4.1 while $\mathrm{O}_{2} / \mathrm{Ar}$ ratios are stable and close to the ratio of the atmospheric equilibrium $\left[\mathrm{O}_{2(\mathrm{aq})}\right]_{\mathrm{eq}} /\left[\mathrm{Ar}_{(\mathrm{aq})}\right]_{\mathrm{eq}}=20.4$. On the contrary, the trend described by $\mathrm{CO}_{2} / \mathrm{Ar}$ ratios decrease constantly from $7 \mathrm{~h} 00$ to $14 \mathrm{~h} 30$ while $\mathrm{O}_{2} / \mathrm{Ar}$ ratios increase between $7 \mathrm{~h} 00$ to $10 \mathrm{~h} 30$, then stabilise around 24.0 between $10 \mathrm{~h} 30$ and $14 \mathrm{~h} 30$ and eventually decrease until night-time.

The high-frequency dissolved gas data recorded by the CFMIMS (Figure 2 and Figure 3) exhibit the competition between four major hydrobiogeochemical processes in the Avenelles River. The first is the respiration process consisting in a biogenic consumption of the available organic matter and dissolved $\mathrm{O}_{2}$ which is balanced by a release of $\mathrm{CO}_{2}$. Between $14 \mathrm{~h} 30$ and $7 \mathrm{~h} 00$, respiration is the key reaction controlling the decrease of $\mathrm{O}_{2}$ and the increase of $\mathrm{CO}_{2}$ concentrations. The second process displayed by the dissolved gas data is the photosynthesis reaction which consists in a consumption of $\mathrm{CO}_{2}$ and solar energy by plants to produce organic matter and $\mathrm{O}_{2}$. Opposed to respiration processes, photosynthesis reactions control the variations of $\mathrm{CO}_{2}$ and $\mathrm{O}_{2}$ concentrations between $7 \mathrm{~h} 00$ and $14 \mathrm{~h} 30$. As a result, $\mathrm{O}_{2}$ concentrations qualitatively follow the intensity of day-light which is here, the limiting factor for photosynthesis. These observations would obviously benefit from additional measurements of Dissolved Organic Carbon or Photosynthetically Active Radiation which are not shown in this paper. The third process consists in a $\mathrm{CO}_{2}$ rich groundwater discharge (probably $\mathrm{O}_{2}$ rich groundwater as well) during the low water period which is highlighted by the $\mathrm{CO}_{2}$ oversaturation $\left(\left[\mathrm{CO}_{2(\mathrm{aq})}\right]>300 \%\right.$ sat $)$ and by supported radon data $\left(\mathrm{a}\left({ }^{222} \mathrm{Rn}\right)>1 \mathrm{kBq} / \mathrm{m}^{3}\right)$. The last process is the atmosphereriver gas exchange evidenced by the nocturnal stabilisation of $\mathrm{O}_{2}$ concentrations at atmospheric equilibrium levels while dissolved $\mathrm{CO}_{2}$ contents rises proportionally to respiration rates. The latter shows that the atmosphere-river $\mathrm{O}_{2}$ exchange is faster than respiration in the low water period and defines a boundary condition for the aquatic ecosystem $\left(\left[\mathrm{O}_{2(\mathrm{aq})}\right]_{\mathrm{eq}} \leq\right.$ $\left.\left[\mathrm{O}_{2(\mathrm{aq})}\right]\right)$ of the Avenelles River. Due to the continuous $\mathrm{CO}_{2}$ oversaturation in the Avenelles River, the competition between atmosphere-river $\mathrm{CO}_{2}$ exchange, photosynthesis and respiration does not imply such a lower boundary condition. However, in view of our previous observations on the kinetics of atmosphere-river gas exchanges during the experiment, the Avenelles River is probably a source of $\mathrm{CO}_{2(\mathrm{~g})}$ and the dissolved $\mathrm{CO}_{2}$ concentrations are mainly limited by the groundwater discharge rate and the $\mathrm{CO}_{2}$ transfer rate to the atmosphere.

\section{GENERAL DISCUSSION}

The CF-MIMS consists in a promising tool allowing the high-frequency measurement of several dissolved gases (He, $\mathrm{Ne}, \mathrm{Ar}, \mathrm{Kr}, \mathrm{Xe}, \mathrm{N}_{2}, \mathrm{CO}_{2}, \mathrm{O}_{2}, \mathrm{CH}_{4}, \mathrm{~N}_{2} \mathrm{O}$ and $\mathrm{H}_{2}$ ) in the field. The CF-MIMS requires a proper calibration procedure which is not so trivially nor rapidly accomplished because it is performed on SEWs (a precise determination of their dissolved composition is essential) with a flow and temperature dependent membrane permeability (a precise control of these parameter and a good evaluation of their effects is also necessary). When the calibration procedure is properly achieved and as long as the dissolved gas flux is well established between the water flow and the mass spectrometer 
vacuum, the CF-MIMS does not necessitate additional calibration (standard bracketing). The latter would alter the benefits of the continuous measurements since the CF-MIMS measurements require as much stability as possible. For long monitoring experiments we thus recommend a regular sampling to ensure the validity of the calibration. The laboratory test carried out at the laboratory show that the CFMIMS is very suitable for environmental studies in terms of analytical precision, sensitivity and response time.

The high-frequency dissolved gas data recorded with the CF-MIMS in the Avenelles River are in good agreement with analyses obtained with classical validated methods. In comparison with the latter, the field continuous measurements performed with the CF-MIMS enhance considerably the temporal distribution and the quality of dissolved gas data. The field application at the Orgeval Critical Zone Observatory demonstrates the asset of such in situ high frequency monitoring of multiple dissolved gases to observe and understand the key physical (atmosphere-river gas exchanges \& groundwater-river exchanges) and biogeochemical (photosynthesis \& respiration) processes that shape the Critical Zone.

To conclude, the development of the CF-MIMS enables to produce field continuous dissolved gas data and to enhance both the spatial-temporal distribution and the quality of environmental data for a thorough exploration of the Hydrosphere. This "operational hydrogeochemistry" contributes in the end to bring back environmental scientists on the field to get a much more detailed understanding of the structures, the properties and the processes at stake in the Critical Zone.

\section{ACKNOWLEDGMENTS}

This study was funded by the CRITEX project (ANR-11EQPX-0011) and the Condate Eau platform (OSUR/Univ Rennes). The authors would like to thank Hiden Analytical especially for the high quality of their customer service. We are also grateful to Christophe Petton and Nicolas Lavenant for their technical help in the conception and building of the calibration chamber.

\section{REFERENCES}

[1] Benson, A., Zane, M., Becker, T.E., Visser, A., Uriostegui, S.H., DeRubeis, E., Moran, J.E., Esser, B.K., Clark, J.F. (2014). Quantifying reaeration rates in alpine streams using deliberate gas tracer experiments. Water, 6(4): 1013-1027. https://doi.org/10.3390/w6041013

[2] Wanninkhof, R., Asher, W.E., Ho, D.T., Sweeney, C., McGillis, W.R. (2009). Advances in quantifying air-sea gas exchange and environmental forcing. Ann Rev Mar Sci. 1:

213-244 https://doi.org/10.1146/annurev.marine.010908.163742

[3] Aeschbach-Hertig, W., Peeters, F., Beyerle, U., Kipfer, R. (1999). Interpretation of dissolved atmospheric noble gases in natural waters. Water Resour Res., 35(9): 2779 2792. https://doi.org/10.1029/1999WR900130

[4] Chatton, E., Aquilina, L., Petelet-Giraud, E., Cary, L., Bertrand, G., Labasque, T., Hirata, R., Martins, V., Montenegro, S., Vergnaud, V., Aurouet, A., Kloppmann, W., Pauwels. (2016). Glacial recharge, salinisation and anthropogenic contamination in the coastal aquifers of Recife (Brazil). Sci Total Environ., 569-570: 1114-1125. https://doi.org/10.1016/j.scitotenv.2016.06.180

[5] Lehmann, B.E., Purtschert, R. (1997). Radioisotope dynamics - The origin and fate of nuclides in groundwater. Appl Geochemistry, 12(6): 727-738. https://doi.org/10.1016/S0883-2927(97)00039-5

[6] Lehmann, B.E., Love, A., Purtschert, R., Collon, P., Loosli, H.H., Kutschera, W., Beyerle, U., AeschbachHertig, W., Kipferd, R., Frape, S.K., Herczeg, A., Moran, J., Tolstikhin, I.N., Gröning, M. (2003). A comparison of groundwater dating with $81 \mathrm{Kr}, 36 \mathrm{Cl}$ and $4 \mathrm{He}$ in four wells of the Great Artesian Basin, Australia. Earth Planet Sci Lett., 211(3-4): 237-250. https://doi.org/10.1016/S0012-821X(03)00206-1

[7] Wanninkhof, R., Mulholland, P.J., Elwood, J.W. (1990). Gas exchange rates for a first-order stream determined with deliberate and natural tracers. Water Resour Res., 26(7): https://doi.org/10.1029/WR026i007p01621

[8] Chatton, E., Labasque, T., de La Bernardie, J., Guihéneuf, N., Bour, O., Aquilina, L. (2017). Field continuous measurement of dissolved gases with a CF-MIMS: applications to the physics and biogeochemistry of groundwater flow. Environ Sci Technol., 51(2): 846-854. https://doi.org/10.1021/acs.est.6b03706

[9] Beaulieu, J.J., Tank, J.L., Hamilton, S.K., et al. (2011). Nitrous oxide emission from denitrification in stream and river networks. Proc Natl Acad Sci U S A, 108(1): 214219. https://doi.org/10.1073/pnas.1011464108

[10] Cole, J.J., Prairie, Y.T., Caraco, N.F., McDowell, W.H., Tranvik, L.J., Striegl, R.G., Duarte, C.M., Kortelainen, P., Downing, J.A., Middelburg, J.J., Melack, J. (2007). Plumbing the global carbon cycle: Integrating inland waters into the terrestrial carbon budget. Ecosystems, 10: 171-184. https://doi.org/10.1007/s10021-006-9013-8

[11] Gardner, J.R., Fisher, T.R., Jordan, T.E., Knee, K.L. (2016). Balancing watershed nitrogen budgets: accounting for biogenic gases in streams. Biogeochemistry, 127: 231-253. https://doi.org/10.1007/s10533-015-0177-1

[12] Raymond, P.A., Hartmann, J., Lauerwald, R., et al. (2013). Global carbon dioxide emissions from inland waters. Nature, 503: 359.https://doi.org/10.1038/nature 12760

[13] Riley, A.J., Dodds, W.K. (2013). Whole-stream metabolism: Strategies for measuring and modeling diel trends of dissolved oxygen. Freshw Sci., 32(1): 56-69. https://doi.org/10.1899/12-058.1

[14] An, S., Gardner, W.S., Kana, T.M. (2001). Simultaneous measurement of denitrification and nitrogen fixation using isotope pairing with membrane inlet mass spectrometry analysis. Appl Environ Microbiol., 67: 1171-1178. https://doi.org/10.1128/AEM.67.3.1171

[15] Bohatka, S., Futo, I., Gal, I., Gal, J., Langer, G., Molnar, J., Szádai, J., Székely, G. (1993). Quadrupole mass spectrometer system for fermentation monitoring. Vacuum, 44(5-7): 669-671. https://doi.org/10.1016/0042-207X(93)90121-P

[16] Cowie, G., Lloyd, D. (1999). Membrane inlet ion trap mass spectrometry for the direct measurement of dissolved gases in ecological samples. J Microbiol Methods, 35(1): 1-12. https://doi.org/10.1016/S01677012(98)00090-6 
[17] Degn, H. (1992). Membrane inlet mass spectrometry in pure and applied microbiology. J Microbiol Methods, 15(3): $\quad$ 185-197. $\quad$ https://doi.org/10.1016/01677012(92)90039-7

[18] Eschenbach, W., Well, R. (2011). Online measurement of denitrification rates in aquifer samples by an approach coupling an automated sampling and calibration unit to a membrane inlet mass spectrometry system. Rapid Commun Mass Spectrom, 25(14): 1993-2006. https://doi.org/10.1002/rcm.5066

[19] Kana, T.M., Darkangelo, C., Hunt, M.D., Oldham, J.B., Bennett, G.E., Cornwell, J.C. (1994). Membrane inlet mass spectrometer for rapid high-precision determination of $\mathrm{N}_{2}, \mathrm{O}_{2}$, and $\mathrm{Ar}$ in environmental water samples. Anal Chem., 66(23): 4166-4170. https://doi.org/10.1021/ac00095a009

[20] Lauritsen, F.R., Bohatka, S., Degn, H.A. (1990). Membrane-inlet tandem mass spectrometer for continuous monitoring of volatile organic compounds. Rapid Commun Mass Spectrom., 4: 401-403.

[21] Lloyd, D., Scott, R.I. (1983). Direct measurement of dissolved gases in microbiological systems using membrane inlet mass spectrometry. J Microbiol Methods, 1(6): $\quad 313-328 . \quad$ https://doi.org/10.1016/01677012(83)90008-8

[22] Takahata, N., Igarashi, G., Sano, Y. (1997). Continuous monitoring of dissolved gas concentrations in groundwater using quadrupole mass spectrometer. Appl Geochemistry, 12(4): 377-382. https://doi.org/10.1016/S0883-2927(97)00007-3

[23] Bell, R.J., Short, R.T., Van Amerom, F.H.W., Byrne, R.H. (2007). Calibration of an in situ membrane inlet mass spectrometer for measurements of dissolved gases and volatile organics in seawater. Environ Sci Technol., 41(23): 8123-8128. https://doi.org/10.1021/es070905d

[24] Brennwald, M.S., Schmidt, M., Oser, J., Kipfer, R. (2016). A portable and autonomous mass spectrometric system for on-site environmental gas analysis. Environ Sci Technol., 50(24): 13455-13463. https://doi.org/10.1021/acs.est.6b03669

[25] Gentz, T., Schlüter, M. (2012). Underwater cryotrapmembrane inlet system (CT-MIS) for improved in situ analysis of gases. Limnol Oceanogr Methods, 10(5): 317-328. https://doi.org/10.4319/lom.2012.10.317

[26] Hemond, H.F. (1991). A backpack-portable mass spectrometer for measurement of volatile compounds in the environment. Rev Sci Instrum., 62(6): 1420. https://doi.org/10.1063/1.1142461

[27] Ketola, R.A., Kotiaho, T., Cisper, M.E., Allen, T.M. (2002). Environmental applications of membrane introduction mass spectrometry. J Mass Spectrom., 37(5): 457-476. https://doi.org/10.1002/jms.327

[28] Kotiaho, T. (1996). On-site environmental and in situ process analysis by mass spectrometry. J Mass Spectrom., 31(1): 1-15. https://doi.org/10.1002/(SICI)10969888(199601)31:1<1::AID-JMS295>3.0.CO;2-J

[29] Mächler, L., Brennwald, M.S., Kipfer, R. (2012). Membrane inlet mass spectrometer for the quasicontinuous on-site analysis of dissolved gases in groundwater. Environ Sci Technol., 46(15): 8288-8296. https://doi.org/10.1021/es3004409
[30] Manning, C.C., Stanley, R.H.R., Lott, D.E. (2016). Continuous measurements of dissolved $\mathrm{Ne}, \mathrm{Ar}, \mathrm{Kr}$, and $\mathrm{Xe}$ ratios with a field-deployable gas equilibration mass spectrometer. Anal Chem., 88(6): 3040-3048. https://doi.org/10.1021/acs.analchem.5b03102

[31] Short, R.T., Fries, D.D., Kerr, M.L., Lembke, C.E., Toler S.K., Wenner, P.G., Byrne, R.H. (2001). Underwater mass spectrometers for in-situ chemical analysis of the hydrosphere. J Am Soc Mass Spectrom., 12(6): 676-682. https://doi.org/10.1016/S1044-0305(01)00246-X

[32] Tortell, P.D. (2005). Dissolved gas measurements in oceanic waters made by membrane inlet mass spectrometry. Limnol Oceanogr Methods, 3(1): 24-37. https://doi.org/10.4319/lom.2005.3.24

[33] Virkki, V.T., Ketola, R.A., Ojala, M., Kotiaho, T., Komppa, V., Grove, A., Facchetti, S. (1995). On-site environmental analysis by membrane inlet mass spectrometry. Anal Chem., 67(8): 1421-1425. https://doi.org/10.1021/ac00104a019

[34] Visser, A., Singleton, M.J., Hillegonds, D.J., Velsko, C.A., Moran, J.E., Esser, B.K. (2013). A membrane inlet mass spectrometry system for noble gases at natural abundances in gas and water samples. Rapid Commun Mass $\quad$ Spectrom., 27(21): 2472-2482. https://doi.org/10.1002/rcm.6704

[35] White, A.J., Blamire, M.G., Corlett, C.A., Griffiths, B.W., Martin, D.M., Spencer, S.B., Mullock, S.J. (1998). Development of a portable time-of-flight mebrane inlet mass spectrometer for environmental analysis. Rev Sci Instrum., 69(2): 565. https://doi.org/10.1063/1.1148695

[36] Clever, H.L. (1979). Helium and Neon - Gas Solubilities. Solubility Data Ser.

[37] Clever, H.L. (1979). Krypton, Xenon and Radon - GasSolubilities. Solubility Data Ser.

[38] Clever, H.L. (1980). Argon. Solubility Data Ser.

[39] Smith, S.P., Kennedy, B.M. (1983). The solubility of noble gases in water and in $\mathrm{NaCl}$ brine. Geochim Cosmochim Acta., 41: 503-515.

[40] Weiss, R.F. (1970). The solubility of nirogen, oxygen and argon in water and seawater. Deep Res., 17: 721-735.

[41] Weiss, R.F. (1974). Carbon dioxide in water and seawater: the solubility of a non-ideal gas. Mar Chem., 2(3): 203-215. https://doi.org/10.1016/03044203(74)90015-2

[42] Weiss, R.F., Price, B.A. (1980). Nitrous oxide solubility in water and seawater. Mar Chem., 8(4): 347-359. https://doi.org/10.1016/0304-4203(80)90024-9

[43] Wiesenburg, D.A., Guinasso, N.L. (1979). Equilibrium solubilities of methane, carbon monoxide, and hydrogen in water and sea water. J Chem Eng Data, 24(4): 356-360. https://doi.org/10.1021/je60083a006

[44] Floury, P., Gaillardet, J., Gayer, E., Bouchez, J., Tallec, G., Ansart, P., Koch, F., Gorge, C., Blanchouin, A., Roubaty, J.L. (2017). The potamochemical symphony: New progress in the high-frequency acquisition of stream chemical data. Hydrol Earth Syst Sci., 21(12): 6153-6165. https://doi.org/10.5194/hess-21-6153-2017

[45] Sugisaki, R., Taki, K. (1987). Simplified analyses of He, $\mathrm{Ne}$, and $\mathrm{Ar}$ dissolved in natural waters. Geochem J., 21(1): 23-27. https://doi.org/10.2343/geochemj.21.23 